\title{
Administrative, legal, natural, and socioeconomic factors that impede the functioning and development of inland fisheries in Poland
}

\author{
Maciej Mickiewicz, Arkadiusz Wołos
}

Received - 11 June 2014/Accepted - 10 October 2014. Published online: 31 December 2014; Inland Fisheries Institute in Olsztyn, Poland Citation: Mickiewicz M., Wołos A. 2014 - Administrative, legal, natural, and socioeconomic factors that impede the functioning and development of inland fisheries in Poland - Arch. Pol. Fish. 22: 281-288.

\begin{abstract}
The results of a questionnaire survey of the managers of fisheries enterprises entitled to operate in fisheries zones are presented. The aim of the study was to determine the degree to which selected factors have a negative impact on the functioning and development of fisheries. The impediment posed by the different factors was determined with a rating scale. The factors that posed impediments were ranked, from greatest to smallest, as follows: cormorant predation on ichthyofauna; commercial and recreational fisheries poaching; national and local administrations (e.g., flawed laws, bureaucracy, incompetence, etc.); unenforced regulations and laws or the lack of them; excessive leasing fees; water eutrophication and pollution; development of recreation linked with the aquatic environment; eco-terrorism, other fees payable to the state in addition to leasing fees; difficulties with selling fish; recreational fisheries pressure.
\end{abstract}

Keywords: inland fisheries, inhibited development and functioning, factors: administrative, legal, natural, socioeconomic

\footnotetext{
M. Mickiewicz [ $\left.\Xi^{\circ}\right]$, A. Wołos

Department of Fisheries Bioeconomics

Inland Fisheries Institute in Olsztyn

ul. Oczapowskiego 10, 10-719 Olsztyn, Poland

Tel. +48 89 5241065; e-mail: mmickiewicz@infish.com.pl
}

\section{Introduction}

Inland fisheries, especially those performed in natural water bodies, are open systems according to the basic criteria of the systemic approach; apart from the intrinsic elements comprising such systems and their mutual interactions, they are indirectly under the influence of factors that comprise, as is understood by the systemic approach, the environment (Carter et al. 1988). The fundamental elements of this system include: fish populations; commercial and/or recreational fisheries exploitation; restocking and other fisheries management measures; the state of the aquatic ecosystem. The environment of this system comprises many aspects from basin use and recreation, the quality of and compliance with laws that govern fisheries exploitation of waters and administrative actions, to climate and weather conditions, and micro- and macroeconomic factors. It is noteworthy that fisheries has practically no impact on most of these factors from the system environment, and that often they have considerable impact on the functioning, including negatively, of the entire system. SWOT analysis is one method that is used widely to identify the most important factors that impede or threaten the functioning and development of many branches of economies (Pahl and Richter 2009). In 
Poland, this has included, among other examples, applying SWOT during the development of regional and national diagnostic and strategic documents (Wołos and Mickiewicz 2012a). Identifying these factors based largely on unmeasurable expert knowledge did not lead to quantifying them measurably.

In 1998, the Department of Fisheries Bioeconomics at IFI in Olsztyn conducted a survey study of enterprises that exploited mainly lake fisheries districts. The aim of the study was to identify and quantify the factors that inhibited the functioning and development of lake fisheries (Bnińska 1998). Sixty-nine managers of fisheries enterprises returned the questionnaires. The study identified 11 factors that impeded the functioning and development of lake fisheries and quantified them according to the opinions of the managers of fisheries enterprises (Bnińska 1998).

This publication was compiled from a survey conducted in early 2014 using the same study methodology as Bnińska (1998). The aim of this paper is to analyze the negative impact of different factors on the functioning and development of fisheries and to identify the changes that have occurred over the past 16 years since 1998 .

\section{Materials and methods}

In February and March 2014, a survey was conducted among managers of enterprises (both legal and physical personalities) engaged in fisheries in the waters of fisheries zones. The participants included owners, presidents, directors, and specialists, most of whom held degrees in inland fisheries and were experienced in conducting sustainable fisheries management. Precisely because of their expertise, experience, and engagement in fisheries practices, they are the most competent persons to asses how various factors impede the functioning and development of fisheries.

Survey questionnaires were sent to 160 potential respondents by mail, and 108 surveys were returned
(67.5\%) from enterprises that exploit close to 294,000 ha of waters, including those in fisheries zones and those used by the National Parks. The return rate of the survey was very satisfactory, as was the surface area of the waters exploited by the enterprises from which responses were obtained. The water surface area covered by the survey was in excess of $75 \%$ of the waters analyzed in a statistical study of inland fisheries conducted within the project entitled Public Statistics Research Program for 2012 (Draszkiewicz-Mioduszewska et al. 2014).

The survey questionnaire included the following factors that impede the functioning and development of fisheries that had been identified previously by Bnińska (1998):

- eutrophication and water pollution;

- commercial and recreational fisheries poaching;

- insufficient enforcement of legal regulations or the lack of them;

- excessive leasing fees;

- other fees payable to the state in addition to leasing fees;

- difficulty selling fish;

- development of aquatic recreation;

- recreational fisheries pressure;

- eco-terrorism;

- national and local administrations (e.g., flawed laws, bureaucracy, incompetence, etc.);

- cormorant pressure on ichthyofauna;

- other (specified by respondents).

Fisheries enterprise managers were asked to rate the negative impact of each of these factors on a scale from 5 to 0 , with 5 indicating factors that had highly negative impacts and 0 - factors with virtually no negative impact. This methodological approach permitted ranking the factors mentioned above. The results are presented as the share (\%) of the highest possible rank and as the mean rank. The highest possible rank was $100 \%$ when all respondents gave a factor the highest rank of five. This means that in the case of all of the samples analyzed (108 respondents), $100 \%$ corresponds to the product of $108 \times 5$, or 540 points. The size of the average rank is the arithmetic average of the sum of all ranks attributed to the factor (in the case of the highest possible rank it 
is the quotient of 540/108 = 5). The mean ranks obtained were divided as follows:

- From 0 to 1 - factor with virtually no negative impact;

- From 1 to 2 - factor with little negative impact;

- From 2 to 3 - factor with moderate negative impact;

- From 3 to 4 - factor with significant negative impact;

- From 4 to 5 - factor with highly negative impact.

\section{Results and discussion}

In the opinion of the fisheries enterprise managers, the factors that had the greatest negative impact (factor with significant negative impact) on the functioning and development of the fisheries were as follows (Table 1): cormorant predation on ichthyofauna; commercial and recreational poaching; national and local administrations (e.g., flawed laws, bureaucracy, incompetence, etc.); insufficient enforcement of legal regulations or the lack of them. The mean rank of these factors was in the 3 to 4 point range.

Cormorant predation on ichthyofauna was designated as a factor with a highly negative impact on fisheries management ( 5 point range) by 55 of the 108 respondents or $51 \%$ of those surveyed. Poaching, national and local administrations, and insufficient enforcement of legal regulations or the lack of them were ranked at 26, 29, and $21 \%$, respectively.

Further, as factors with moderate negative impacts (mean rank from 2 to 3 points) on the functioning and development of fisheries the respondents designated excessive leasing fees, eutrophication and water pollution, the development of aquatic recreation, eco-terrorism, and other fees payable to the state in addition to leasing fees. Excessive leasing fees was designated as a factor with a highly negative impact (rank of 5 points) by $25 \%$ of the respondents, eutrophication and water pollution by $7 \%$ of the respondents, the development of aquatic recreation by
$7 \%$ of the respondents, while eco-terrorism and other fees payable to the state in addition to leasing fees by $17 \%$ and $8 \%$ of respondents, respectively.

Difficulty selling fish and recreational fisheries pressure were ranked as factors that had little negative impact on the functioning and development of fisheries (factor with little negative impact, mean rank from 1 to 2 points). The first of these was designated as a factor with a highly negative impact (rank of 5 points) by $4 \%$ of the respondents, while the second by $3 \%$.

It must be underscored that the respondents also designated other factors, which, in their opinions, had a negative impact on the functioning and development of fisheries. Usually, though, they only mentioned them without ranking the degree of their impact on the scale from 5 to 0 . The decided majority among these were wild animals associated with aquatic ecosystems and included herons, otters, mink, beavers, ducks, grebes and white-tailed eagles. These animals were mentioned by 24 respondents, which was more than $22 \%$. The next factor was the "European Union and Polish bureaucracy” in general (6 respondents, 6\%), the lack of a professional fisheries workforce, the lack of a national aquatic ecosystem status monitoring system (ichthyofauna, protected animals, state of the environment) and the lack of subsidies for restocking (3 respondents, 3\%), no access to lakes and fenced shores, too few State Fisheries Guard agents, the lack of steam continuity and drainage, and Natura 2000 areas ( 2 respondents, $2 \%$ ). Single respondents noted some very interesting factors that had a negative impact on the functioning and development of fisheries, including the lack of a fisheries lobby, the negative attitude of the public regarding fisheries management, the lack of direct EU subsidies per hectare of lake surface area exploited, the lack of compensation for damage cause by cormorants, and the lack of experts employed at the Regional Water Management Boards responsible for fisheries management on behalf of the state in fisheries districts. It is worth underscoring that most of the factors designated by the respondents as having a negative impact on the functioning and development of fisheries corresponded to those listed in the survey 


\section{TABLE 1}

Degree of negative impact of different factors on the functioning and development of fisheries in descending order

\begin{tabular}{|c|c|c|c|c|c|}
\hline Order & $\begin{array}{l}\text { Factors that have a negative impact on the } \\
\text { functioning and development of fisheries }\end{array}$ & $\begin{array}{l}\text { Degree of negative im- } \\
\text { pact in } \% \text { of the maxi- } \\
\text { mum possible rank sum }\end{array}$ & $\begin{array}{l}\text { Mean } \\
\text { ranking }\end{array}$ & $\begin{array}{l}\text { Degree of negative } \\
\text { impact in } \% \text { of the } \\
\text { maximum possible } \\
\text { rank sum }{ }^{1}\end{array}$ & $\begin{array}{l}\text { Mean } \\
\text { ranking }\end{array}$ \\
\hline 1 & Cormorant predation on ichthyofauna & 79.8 & 3.99 & 64.6 & 3.23 \\
\hline 2 & Commercial and recreational poaching & 73.0 & 3.65 & 89.3 & 4.46 \\
\hline 3 & $\begin{array}{l}\text { National and local administrations (e.g., flawed } \\
\text { laws, bureaucracy, incompetence, etc.) }\end{array}$ & 65.0 & 3.25 & 52.5 & 2.62 \\
\hline 4 & $\begin{array}{l}\text { Insufficient enforcement of legal regulations or } \\
\text { the lack of them }\end{array}$ & 60.7 & 3.04 & 72.2 & 3.61 \\
\hline 5 & Excessive leasing fees & 56.1 & 2.81 & 60.6 & 3.03 \\
\hline 6 & Eutrophication and water pollution & 51.1 & 2.56 & 62.6 & 3.13 \\
\hline 7 & Development of aquatic recreation & 48.5 & 2.43 & 49.0 & 2.45 \\
\hline 8 & Eco-terrorism & 44.8 & 2.24 & 46.7 & 2.33 \\
\hline 9 & $\begin{array}{l}\text { Other fees payable to the state in addition to } \\
\text { leasing fees }\end{array}$ & 40.6 & 2.03 & 53.3 & 2.67 \\
\hline 10 & Difficulty selling fish & 31.5 & 1.57 & 43.2 & 2.16 \\
\hline 11 & Recreational fisheries pressure & 29.3 & 1.46 & 26.7 & $>2.00$ \\
\hline
\end{tabular}

${ }^{1}$ according to Bnińska (1998), modified

questionnaire, for example, wild animals correspond to cormorant pressure, and European Union and Polish bureaucracy corresponds to national and local administrations.

The first study of factors that have a negative impact on the functioning and development of fisheries in Poland was conducted in 1998 (Bnińska 1998), which was at the beginning of the ownership transformation in Polish fisheries. Today, fisheries management in fisheries zones waters (lakes, rivers, dam reservoirs) has been functioning in the free market for about twenty years; therefore, it is very interesting to compare the results Bnińska (1998) obtained with those presented in this paper.

Table 1 is also a synthetic presentation of the results Bnińska (1998) obtained based on a sample size of 69 respondents - managers of fisheries enterprises in Polish lake districts. In the opinion of fisheries enterprise managers in 1998, the factor that had the most negative impact on the functioning and development of fisheries (mean rank from 4 to 5) was commercial and recreational poaching (Table 1). This factor scored $89.3 \%$ of the maximum possible rank sum with a mean rank of 4.46 points. This means that $64 \%$ of respondents designated this factor as having a highly negative impact. In 2014, none of the factors studied was designated as being as highly negative as this.

Factors with a significant negative impact (mean rank form 3 to 4 points) in 1998 included insufficient enforcement of legal regulations or the lack of them (mean rank 3.61), cormorant pressure on ichthyofauna (mean rank 3.23), eutrophication and water pollution (mean rank 3.13), and excessive leasing fees (mean rank 3.03). In 1998, the factors that had a moderately negative impact on the functioning and development of fisheries (mean rank from 2 to 3 points) included other fees payable to the state in addition to leasing fees (mean rank 2.67), national and local administrations (e.g., flawed laws, bureaucracy, incompetence, etc., etc.) (mean rank 2.62), the development of aquatic recreation (mean rank 2.45), eco-terrorism (mean rank 2.33), and difficulty selling fish (mean rank 2.16). In the 1998 survey, similarly to 2014, recreational fisheries was ranked last among the factors that have a negative impact on the functioning and development of fisheries.

The comparison of the surveys from 1998 and 2014 indicated that respondents in 1998 evaluated 
the factors with slightly more severity. The two rankings can be compared synthetically by referring the results of the 2014 survey to those of the 1998 survey as follows:

- cormorant predation on ichthyofauna - up from third position to first;

- commercial and recreational poaching - down from first to second position;

- national and local administrations (e.g., flawed laws, bureaucracy, incompetence, etc.) - up from seventh position to third;

- insufficient enforcement of legal regulations or the lack of them - down from second position to fourth;

- excessive leasing fees - same position in both rankings;

- eutrophication and water pollution - down from fourth position to sixth;

- development of aquatic recreation - up from eight position to seventh;

- eco-terrorism - up from ninth position to eighth;

- other fees payable to the state in addition to leasing fees - down from sixth position to ninth;

- difficulty selling fish - same position in both rankings;

- recreational fisheries pressure - same position in both rankings.

When examining changes in the significance of the different factors that impeded the functioning and development of fisheries in 1998 and 2014, it seems to be unnecessary to comment on factors that moved one or two positions up or down in the rankings, since this indicates the negative impact of these factors on those who exploit the fisheries of lakes, rivers, and dam reservoirs remained more or less stable. It is noteworthy that cormorant pressure on ichthyofauna moved up two positions in the 2014 ranking in comparison to that of 1998 (from third to first position), as is the downward movement from first to second position of commercial and recreational poaching. Moreover, eutrophication and water pollution moved downward from fourth position to sixth, insufficient enforcement of regulations and the lack of them moved down from second position to fourth, and difficulty selling fish was ranked at the same position in both surveys.

With regard to the first factor, the explanation is simple: the cormorant population has increased significantly in the 16 years between the two surveys, and along with this the pressure this species exerts on ichthyofauna has increased. Not only have researchers interested in cormorant populations noted this (Adamek et al. 1997, Trolliet 1999, Cosolo et al. 2010, Bzoma et al. 2013), most fisheries enterprise managers have done so too, as is indicated by the present survey. Indirect evidence of this can also be found in the responses of fisheries enterprise managers who reported very poor evaluations of institutions responsible for the cormorant population in Poland (e.g., Ministry of the Environment, Director General for Nature Conservation, Regional Directors for Nature Conservation) and of the functioning of state administrative organs at the European Union, national, and regional levels. These were confirmed by the results of the 2014 survey. Additionally, although the importance of cormorant pressure on ichthyofauna increased relatively insignificantly in the ranking (by two positions), the negative impact of this factor measured as the percentage of the maximum possible rank sum increased significantly from approximately $65 \%$ in 1998 to approximately $80 \%$ in 2014 , which is a 15 point percentage increase (Table 1 ).

The fact that commercial and recreational poaching fell in the ranking from first position in 1998 to second in 2014 as a factor that impedes the functioning and development of fisheries is also confirmed by opinions from the services responsible for combating this phenomenon and studies of it (Czerwiński 2009, NIK 2014). While the significance of commercial and recreational poaching decreased only slightly in the ranking, the degree of its negative impact measured as the percentage of the maximum possible rank sum decreased very clearly from approximately 89\% in 1998 to approximately $73 \%$ in 2014, which is 16 percentage points (Table 1). One can also infer reasonably that the "center of gravity" of poaching has shifted since 1998 from intensive, structured, profit-driven poaching toward a more 
“recreational” poaching (Czerwiński 2009), thus from commercial poaching to recreational poaching. This is somewhat simplified; as commercial poaching has declined, recreational poaching, which includes angling without a fishers card or purchasing a license, exceeding catch limits, and fishing during closed seasons, has certainly remained at a similar level.

The decreasing negative impact of eutrophication and water pollution (down two positions but also 12 percentage points) appears to be understandable. From 1998 to the present, public awareness of the necessity of conserving waters and the requisite, significant financial investment in, for example, sewage treatment facilities, has increased significantly. Moreover, the quantity of fertilizers used in agriculture has decreased substantially, they have become less environmentally invasive, and are used more rationally, all of which has been effected by addressing the costs of their use more realistically. That the environments of many lakes have improved is evidenced not only by improved basic hydrobiological parameters, but also by the advantageous shift in the species structure of catches that is noted by those who exploit the waters (Czerwiński and Wołos 2001, Wołos and Falkowski 2007, Wołos et al. 2009, Zdanowski et al. 2009).

The decrease in the ranking of the factor pertaining to difficulty selling fish (despite being in the same position in each ranking, the negativity of its impact decreased by 11 percentage points) also appears to be evident. Although fish, and particularly valuable freshwater species, have always been considered to be a luxury food item in Poland, one can assume that increased public awareness of the health benefits provided by fish consumption and the increasing wealth of Polish society has also driven increased demand for this type of food. The decreased fishing effort reflected in the near two-fold decrease in the efficiency of lake fisheries catches from $14.04 \mathrm{~kg} \mathrm{ha}^{-1}$ in 1998 (Leopold and Wołos 1999) to $7.94 \mathrm{~kg} \mathrm{ha}^{-1}$ in 2012 (Wołos et al. 2013) cannot be ruled out as having affected this factor. All of these factors have contributed to decreased difficulty selling fish.

It is more difficult to interpret the decrease in the negative impact of insufficiently enforced regulations or the lack of them (down two positions in the ranking, and also 11 percentage points). On the one hand, the number of regulations pertaining to inland fisheries and broadly understood water conservation has certainly increased since 1998 as has their enforcement (Czerwiński 2009, NIK 2014). On the other hand, one can assume that with the increased market and financial stability of the fisheries enterprises the negative impact this factor, in the opinion of their managers, has decreased. However, interpreting unequivocally whether or not the negative impact of the insufficient enforcement of regulations or the lack of them has decreased is exceedingly difficult.

Finally, shifts of three or four positions in the rankings must be commented on. The first of these is the downward shift in the negative impact of other fees payable to the state in addition to leasing fees (from third to sixth position). It is noteworthy that this decrease measured as the percentage of the maximum possible rank sum decreased from approximately 53\% in 1998 to approximately $41 \%$ in 2014 , which is a decrease of 12 percentage points. It could be simply that financial obligations to the state have decreased since 1998. This, however was not the case: during this period costs of labor, VAT, insurance, health insurance, etc. all increased. Therefore, it can be reasonably assumed that the majority of fish farms are coping better with these obligations. In 1998, the fisheries were functioning just following the ownership transformation, and operating in the free market was new. After 16 years, nearly all fisheries enterprises have established positions on the market, have diversified their businesses, and are earning increased revenue (including, in particular, from endeavors outside of the fisheries that are not associated with selling fishing licenses), and thus, they have achieved a certain level of financial and market stability, the best proof of which is the overall increase in fishing enterprise revenue from 100 million PLN in 1998 (Leopold and Wołos 1999) to 150 million PLN in 2012 (Wołos et al. 2013), which is an increase of 50\%. Funding from the European Union has also played a role in this process (Czerwiński 2011). It would seem, however, that the stronger market 
position of fisheries enterprises and not reduced financial obligations to the state has influenced the decline from 1998 to 2014 in the negative impact of the factor of other fees payable to the state in addition to leasing fees.

The last of the factors that had a negative impact on the development and functioning of the fisheries, and one that moved up the most in the 2014 ranking in comparison to that of 1998, was national and local administrations (e.g., flawed laws, bureaucracy, incompetence, etc.). In Bnińska's (1998) ranking this factor was in position seven, while in the current study it moved up to position three; the upward movement of four positions was the greatest of all the factors studied. The negative impact of this factor measured as the percentage of the maximum possible rank sum increased from approximately 53\% in 1998 to $65 \%$ in 2014 , or by 12 percentage points. It is also worth recalling that in 2014 as many as 58\% of respondents gave this factor the highest negative ranking of 4 or 5 points, while $21 \%$ designated it as of moderate or little negative impact (3 or 2 points). Only $21 \%$ of those surveyed described this factor as virtually not negative ( 1 point) or not relevant ( 0 points). This means that for close to $80 \%$ of respondents the national and local administrations seriously impede the functioning and development of fisheries. It can be assumed reasonably that the increased negative impact of this factor is associated not only with administrative incompetence with regard to inland fisheries and the functioning of its components, but more broadly the administrative inability to perceive the system as a whole, which is something Arlinghaus (2006), among others, has pointed out.

These results correspond to the results of public opinion surveys on the functioning of national and local administrations. In response to the question posed in 2010: "In general, do you agree with the statement that the administration functions well and executes its tasks efficiently and punctually?" close to $50 \%$ of respondents answered "I mostly disagree" (38.2\%) or "I definitely disagree" (11.7\%). In 2006, this percentage was $56 \%$, and in 2007 it was $49 \%$ (Report 2010). In 2011, more than $45 \%$ of respondents replied "I mostly disagree" $(32.2 \%)$ or "I definitely disagree” (13.1\%) (Report 2011).

Based on the facts presented above, one can conclude that fisheries enterprise managers evaluated state and local administrations more severely (a total in excess of $73 \%$ of respondents ranked this factor with 5, 4, and 3 points), than does the general population (just slightly more than $45 \%$ of respondents evaluated the administration negatively in 2011).

\section{Conclusions}

The considerations presented in this paper lead to the conclusion that decreasing the negative impact of most of the factors that effect the functioning and development of fisheries depends on undertaking administrative and legal actions. Besides the eutrophication and pollution of waters, the development of aquatic tourism, and so-called eco-terrorism (although, it seems that impediments from these factors could also be reduced), other negative factors could be eliminated or significantly reduced at three levels:

- implementing simple, rational legislation that takes into consideration inland fisheries as an equal participant in a sustainable economy;

- ensuring compliance with these laws through adequate enforcement by all responsible departments and institutions;

- organizing a simple, competent, and non-bureaucratic administration for parties authorized to exploit the fisheries, and not just one that controls fisheries management.

It will only be possible to implement these measures if adequate funding is provided by the State Treasury, which is the owner of public inland surface waters in which commercial and recreational fisheries are exploited.

Author contributions. M.M. and A.W. designed the research, performed the research, M.M. analysed data, M.M. and A.W. wrote the paper. 


\section{References}

Adamek Z., Klinger H., Staub E. 1997 - Cormorants in Europe - the evaluation of EIFAC/FAO questionnaire campaign - Suppl. Ric. Biol. Selvaggina 26: 347-353.

Arlinghaus R. 2006 - Overcoming human obstacles to conservation of recreational fishery resources, with emphasis on central Europe - Environ. Conserv. 33: 46-59.

Bnińska M. 1998 - Analysis of factors that have a negative impact on the functioning and development of lake fisheries - In: Lake Fisheries - Development, Changes, Challenges (Ed.) A. Wołos, Wyd. IRS, Olsztyn: 105-119 (in Polish).

Bzoma S., Krzywosz T., Betleja J., Orłowska B., Antczak J., Traczuk P., Witkowski J. 2013 - Status of the breeding population of Great Cormorants in Poland in 2012 - In: National reports from the 2012 breeding census of Great Cormorants Phalacrocorax carbo in parts of the Western Palearctic (Eds) T. Bregnballe, J. Lynch, R. Parz-Gollner, L. Marion, S. Volponi, J-Y. Paquet, M.R. van Eerden, IUCN-Wetlands International Cormorant Research Group Report. Technical Report from DCE, Danish Centre for Environment and Energy, Aarhus University. No. 22: 79-81.

Carter R., Martin J., Mayblin B., Munda M. 1988 - Systems, Management and Change - Paul Chapman Publishing Ltd., London.

Cosolo M., Ferrero E.A, Sponza S. 2010 - Prey ecology and behavior affect foraging strategies in the Great Cormorant - Mar. Biol. 157: 2533-2544.

Czerwiński T. 2009 - The problem of poaching in the Warmian-Masurian Voivodeship - In: Diagnosing the current state of and perspectives for the development of inland fisheries and coastal fisheries areas in the Warmian-Masurian Voivodeship (Ed.) A. Wołos, Wyd. IRS, Olsztyn: 155-161 (in Polish).

Czerwiński T. 2011 - Initial evaluation of implementing the Operational Programme "Sustainable Development of Fisheries and Coastal Fishing Areas 2007-2013 (PO Ryby 2007-2013) - In: Sustainable Exploitation of Fisheries Resources and the State of them in 2010 (Ed.) M. Mickiewicz, Wyd. IRS, Olsztyn: 65-69 (in Polish).

Czerwiński T., Wołos A. 2001 - Impact of sewage treatment plants the state of ichthyofauna and fisheries management - In: State of Lake Fisheries in 2000. Selected environmental conditions and administrative and legal functioning of fisheries enterprises (Ed.) A. Wołos, Wyd. IRS, Olsztyn: 50-67 (in Polish).

Draszkiewicz-Mioduszewska H., Wołos A., Mickiewicz M. 2014 - Fisheries management in inland waters in 2012. Part 1. Licensed for fisheries, fisheries zones, commercial catches, and employment - Komun. Ryb. 1: 27-33 (in Polish).

Leopold M., Wołos A. 1999 - Analysis of the state of lake fisheries production in 1998 - In: Lake Fisheries. IV. National Fisheries Conference for Enterprises Exploiting Lakes (Ed.) A. Wołos, Wyd. IRS, Olsztyn: 7-16 (in Polish).

NIK 2014 - Information on the results of monitoring "Fisheries management in State Treasury lakes in the Warmian-Masurian Voivodeship" -

No. 18/2014/P/13/163/LOL. 2014 - Najwyższa Izba Kontroli: 51 p. (in Polish).

Pahl N., Richter A. 2009 - Swot analysis - Idea, Methodology and a Practical Approach - GRIN Verlag: p. 92.

Report 2010 - Report from an Omnibus study on satisfaction with services provided and access to public information in Local Government Unit offices realized by the Foundation for Public Opinion Research Center on contract by the Ministry of Internal Affairs and Administration 2010 - Warszawa, typescript: 50 (Badanie_omnibus_na_temat_satysfakcji_z_obslugi_and_dostepu_do_i nformacji_publicznej_w_urzedach_jednostek_samorzad u_terytorialnego_-_2010_r_) (in Polish).

Report 2011 - Satisfaction with services rendered and access to public information in Local Government Unit offices 2011 - Report from an Omnibus study realized on contract by the Ministry of Internal Affairs and Administration, Warszawa, typescript 79

(TNS_Pentor_Raport_Urzedy-2011) (in Polish).

Trolliet B. 1999 - Répartition et effectifs du Grand Cormoran (Phalacrocorax carbo) en Europe - Game Wildl. 16: 177-223.

Wołos A., Falkowski S. 2007 - Long-term changes in commercial fish catches as a indicators of changes in the trophic of Lake Lubie - economic implications - In: The State of fisheries in lakes, rivers, and dam reservoirs in 2006 (Ed.) M. Mickiewicz, Wyd. IRS, Olsztyn: 69-83 (in Polish).

Wołos A., Mickiewicz M. 2012 - Strategies for fisheries development in the Warmian-Masurian Voivodeship to 2030 - Wyd. IRS, Olsztyn: 138 p. (in Polish).

Wołos A., Zdanowski B., Wierzchowska M. 2009 - Changes in the trophic state of Lake Niegocin based on physical, chemical, biological, and commercial fisheries data Arch. Pol. Fish. 17: 179-194.

Wołos A., Draszkiewicz-Mioduszewska H., Mickiewicz M. 2013 - Analysis of lake fisheries production in 2012 - In: Sustainable exploitation of fisheries resources and their status in 2012 (Ed.) M. Mickiewicz, Wyd. IRS, Olsztyn: 9-19 (in Polish).

Zdanowski B., Wołos A., Wierzchowska M. 2009 - Changes of patterns in the trophic state of Lake Mamry Północne and Lake Niegocin (Masurian Lake District, Poland Limnol. Rev. 9: 39-60. 